\title{
CONTRIBUTION OF TPACK FOR A PEDAGOGICAL CAPABILITY OF VOCATIONAL PRESERVICE TEACHERS IN ELECTRICAL ENGINEERING EDUCATION
}

\author{
Setiadi Cahyono Putro ${ }^{1}$, Wahyu Nur Hidayat ${ }^{2}$, Mahfud Jiono ${ }^{3}$, Ahmad Mursyidun \\ Nidhom $^{4}$, and Junaidi Syarif ${ }^{5}$ \\ ${ }^{1,2,3,4}$ Department of Electrical Engineering, Universitas Negeri Malang, Malang, Indonesia \\ ${ }^{5}$ Department of Mechanical and Nuclear Engineering, University of Sharjah, United Arab Emirates \\ E-mail: setiadi.cahyono.ft@um.ac.id
}

\begin{abstract}
This objective of this study was to reveal the correlation and contribution of Technological Pedagogical Content Knowledge (TPACK) for a pedagogical capability of vocational preservice teachers. The research method used quantitative with a descriptive correlational research design. The research sample consisted of electrical engineering undergraduate students in the Faculty of Engineering at Universitas Negeri Malang. The total samples implemented in this study were 135 students. The data collection used a questionnaire and documentation technique. The reliability of the TPACK questionnaire instrument was 0.972 (Alpha Cronbach). The analysis data technique used the analysis of simple regression. The results of the study revealed a positive correlation and a significant correlation between TPACK and Pedagogical Capability with $\mathrm{R}=0.757$ (psig $0.000<0.05$ ). The contribution of TPACK to Pedagogical Capability in the Vocational Preservice Teacher was R2 $=0.573$.
\end{abstract}

Keywords: electrical engineering education, pedagogical capability, TPACK, vocational teacher

\section{INTRODUCTION}

ASEAN Economic Community (AEC) facing Indonesia greatly influences the development of science, technology, and economy. Quality human resources are enhanced through education channels to face the AEC [1]. Human quality resources pursued through education to achieve success must be supported by professional teachers as well. It is indisputable fact that the logical demands for education to succeed, professional teachers are needed [2], [3]. Teachers are the most important resource that a school should have to achieve greater and better results [4].One of the characteristics of a professional teacher is having qualified high pedagogical abilities. The stages of building the pedagogical ability of a teacher must be trained since they go through the process of studying at undergraduate levels because the ability to achieve it must go through clear stages.

As written in an Indonesian standard of education that pedagogical competence is an ability to manage student learning which includes understanding students, designing and implementing learning, evaluating learning outcomes, and developing students to actualize their various potentials [5], [6]. The condition of the teacher competency test in 2015 conducted by the Ministry of Education and Culture which was followed by all teachers both civil servant and noncivil servant was seen, that the results of the teacher competency test were still under the target set by the Indonesian government. With the average UKG score is 53.02, while the government is targeting an average score 
of 55. Also, the average professional score is 54.77, while the average value of pedagogical competence is only 48.94 .

One of the useful knowledge frameworks for developing teacher or teacher competency competencies is to provide technological pedagogical content knowledge (TPACK) strengthening [7][14]. It is a knowledge framework that shows the relationship between the three knowledge that must be mastered by the teacher, which is; technological knowledge, pedagogical knowledge, and content knowledge. This TPACK needs to be mastered by the teacher so that learning activities can run effectively and efficiently. Another theory was said, TPACK is the development of Shulman's theory in 1986 related to pedagogical content knowledge (PCK) and continues to be developed the same at this time. Various studies both related to TPACK and PCK indicate that it is important knowledge for the development of professional skills of teachers or prospective teachers [15].

According to Asril [16] in general, a teacher must have academic qualifications, competencies, educator certificates, physically and mentally healthy, and can achieve national education goals in Indonesia. As stated in Indonesian Law Number.14 in 2005; Teachers and Lecturers on the competencies possessed of knowledge, skills, and competencies that must be possessed, internalized, controlled by the teacher or lecturer in carrying out their professional duties. It is also supported in the statement of Sagala [17]. He said that what is meant by ability is a combination of mastery, knowledge, skills, values , and attitudes reflected in the mindset and action on every task or job. The teacher competency is a skill, ability, and skills possessed by someone who does his job in educating students to have a good noble and personality as the goal of education [18]. While the pedagogic is a science that not only examines the object to find out how the state or essence of the object (descriptively) but also studies people should act (normatively) [19]. In this case in Indonesia, it is emphasized by his Law number 14 in 2005, that teachers are professional educators with the main tasks, namely: educating, teaching, guiding, directing, training, evaluating, evaluating students in early childhood education formal education pathways, basic education, and secondary education.

According to Alma, et al. [20] pedagogical competence is the ability to manage to learn. This includes the concept of teaching ability which is demonstrated by the mastery of knowledge and teaching skills. Pedagogic competencies that must be possessed by a teacher, among others: an understanding of students, design, implementation, and evaluation of learning. From the description, it can be implemented that pedagogical competence is the ability to manage students. This is also consistent with Indonesian Law which concerning Teachers and Lecturers states that Pedagogic competence is the ability to manage student learning. This theory also said by Mulyasa where the pedagogical competence is the ability of teachers in managing the learning of students which at least includes the following matters; (1) ability to manage learning, (2) understanding of students, (3) learning design, (4) implementation of learning that educates and dialogical, (5) the use of learning technology, (6) implementing learning evaluations, and (7) understanding students' character building [21].

Given that teachers to be professional teachers if they can develop their 
competencies. The use of technology and information is a tool that can be used to achieve competency development goals. The use of technology and information such as the internet can also be used as a medium to improve the professional abilities of teachers. In addition to technology and information can be used as a medium for self-development, but a teacher is also expected to be able to use technology and information in the learning process. Therefore, it can bring up new challenges for a teacher so that each student can apply technology and information in learning. Because students are now familiar with the development of technology and information in their daily lives.

As said by Rosyid that the TPACK idea was first introduced by Shulman in 1986 with the term of PCK which states about the integration of pedagogical knowledge and content knowledge needed in the learning process [22]. According to Shulman, PCK is something very important for a teacher to create learning that is more useful for students. While the theory by Hurrel in 2013 that the PCK can be described as a relationship between basic knowledge about content and pedagogics needed in a learning context. This illustrates the idea of Shulman [15] can be seen in Figure 1.

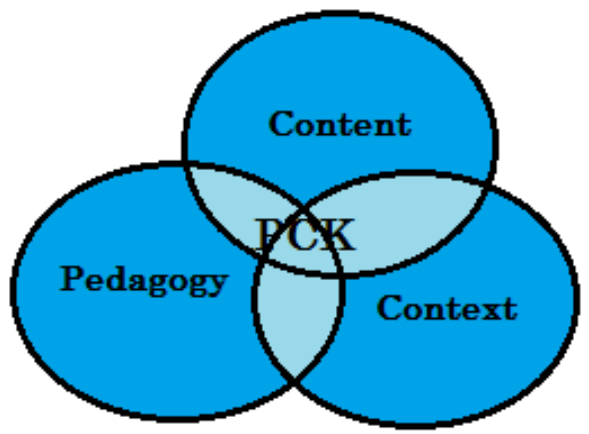

Figure 1. The Domain of Pedagogical Content Knowledge [15]
TPACK is a knowledge framework that shows the relationship between three knowledge that must be mastered by the teacher, namely: technological knowledge, pedagogical knowledge, and content knowledge into learning [23]. This is in the same perspective with Hewitt in 2008 that TPACK is considered as a potential framework in providing new directions for teachers so that they can solve problems that occur in the classroom. It can integrate IT into learning in the classroom.

Based on the opinions of several experts, it can be implemented that TPACK is an educational framework by integrating the three domains of technological knowledge, pedagogical knowledge, and content knowledge in learning. This knowledge can solve problems that occur in the classroom by integrating IT in learning activities. Students also can follow the development of technology and information in the world which fosters development every year.

TPACK is a knowledge framework that illustrates the relationship and complexity between three basic components of knowledge; technology, pedagogy, and content. According to the framework in Figure 2 by Koehler, et al. [23] that the TPACK framework is divided into seven frameworks; technological knowledge (TK), content knowledge (CK), pedagogical knowledge (PK), technological content knowledge ( TCK), pedagogical content knowledge (PCK), technological pedagogical knowledge (TPK) and technological pedagogical content knowledge (TPACK).

Based on Figure 2, TK includes an understanding of how to use various technologies such as the internet, video, interactive whiteboard, and software programs, and presentation tools such as 
document presenters and projects, which can be used in education. The most important TK can include the ability to adapt and learn new technology. On the other hand, CK or content knowledge about the material/content of subjects studied or taught.

According to Shulman [15], that subject matter includes knowledge where a teacher must know and understand the material being taught, understand the characteristics of the material in the form of concepts, theories, ideas, frameworks, methods that are equipped with methods scientific and its application in everyday life. The PK is a set of skills for a teacher so that they can develop ways to manage and manage all teaching and learning activities so that learning outcomes are as expected.

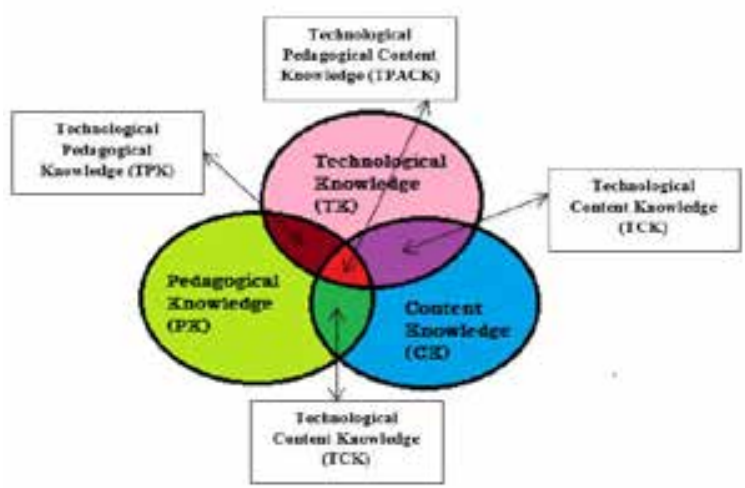

Figure 2. The Framework of Technological Pedagogical Content Knowledge (TPACK) and Its Component [23]

PK relates to teaching methods and processes and includes knowledge in classroom management, assessment, development of learning plans, and student learning activity. While the TCK is knowledge about the reciprocal relationship between technology and content. TCK is knowledge about how technology can create new representations for specific content. By using specific technology, teachers can change the way teachers practice and understand concepts in specific content, such as the application of IT as a means of discussion or a means of communication between teachers and students or students and students with questions related to certain materials.

The PCK is an effective activity in teaching that requires a complex understanding of material knowledge and pedagogical knowledge. This PCK emphasizes how to teach certain material with certain methods to be easily understood by students, by providing students with varied experiences. PCK relates to material knowledge related to the teaching process. TPK is knowledge about how various technologies can be used in teaching activities and the use of these technologies can change the way teachers teach. Technology information is flexible, in addition to being a source of learning it can be used as a medium. Examples of the use of its technology as a learning media animation program.

TPACK is a conceptual framework that shows the relationship between the three knowledge that must be mastered by the teacher, namely technological knowledge, pedagogical knowledge, and content knowledge. This TPACK needs to be mastered by the teacher so that learning activities can run effectively and efficiently. Among them in composing instructional designs, learning models and strategies, assessment systems, and in designing curricula, where all of these are integrated with IT.

It has been explained previously that the success of teaching a teacher is when all students get good grades. This success will never be achieved when the teacher does not yet have learning management skills. Based on the knowledge that they have, will not 
guarantee that a teacher can produce the best output from the results of his education. Therefore the originated the first PCK or knowledge about content which is where a teacher needs to hone his knowledge first [4]. But then that knowledge continues to develop along with the development of technology and information that is increasingly rapid, a teacher must have the skills related to the application of current technological developments.

The recent development of the TPACK framework by Koehler [23] underlines the importance of facilitating student learning not only with content knowledge but also with pedagogical knowledge and technology use. Thus it indicates how important TPACK is for a prospective teacher to get involved in the world of education. A teacher must have a high level of knowledge by utilizing current technology. If TPACK is mastered by prospective teacher students, the prospective student teacher will be able to provide a teaching style that is quite interesting and interactive to achieve the objectives of learning.

The quality of teacher competence in Indonesia has not been evenly distributed and is not following expectations. The quality of teacher competence is a reflection of the reality of education in Indonesia today. Therefore it is needed the three combinations of the TPACK variable to improve the pedagogical capability of the teacher. It is also given in the role of Educational Personnel Institutions as Higher Education Institutions that have a large enough share in preparing and producing teachers who have high pedagogical competencies that can realize the goals of education in Indonesia, by increasing their graduates into professional teacher candidates. Based on these circumstances this research with the topic "Contribution of TPACK for a Pedagogical Capability in the Vocational Preservice Teachers for Electrical Engineering Education" was implemented.

\section{METHOD}

This study uses a descriptive correlational design to determine the relationship between three variables, consisting of two independent variables (exogenous) and one dependent variable (endogenous). The independent variable is technological pedagogical content knowledge (TPACK) as $\mathrm{X}$ variable, while the dependent variable is the pedagogical ability of vocational teacher candidates for electrical engineering education as $\mathrm{Y}$. The population in this study are all students who have taken undergraduate students with a major in electrical engineering education in Universitas Negeri Malang in 2018. The sampling method uses a purposive sampling technique with a saturated sampling type. The saturation sampling technique is a technique for determining the sample if all members of the population are used as samples [24]. The saturation sampling technique was chosen because only the population was only 135 students, so the entire population was sampled.

The research instrument used to measure technological pedagogical content knowledge (TPACK) in the questionnaire or questionnaire measurement method, while to measure the pedagogical abilities of vocational teacher candidates for electrical engineering education by using documentation. The TPACK data obtained by questionnaire with a range of scores from 1 to 4 . It consists of seven indicators; 1 . Technological knowledge (TK), 2. Content knowledge (CK), 3. Pedagogical knowledge 
(PK), 4. Technological content knowledge (TCK), 5. Pedagogical content knowledge (PCK), 6. Technological pedagogical knowledge (TPK), and 7. Technological pedagogical content knowledge (TPACK). The reliability of the TPACK questionnaire instrument was 0.972 (Alpha Cronbach).

According to Arikunto [14], that, "The documentation method is looking for data about things or variables in the form of notes, transcripts, books, newspapers, magazines, inscriptions, minutes of meetings, agendas, and so on". In this study, the document used is the Final Academic Record of the study subjects studied can be seen in Table 1.

Table 1. Educational Subjects

\begin{tabular}{|c|c|c|c|c|}
\hline Variable & $\begin{array}{l}\text { Type of } \\
\text { Subject as } \\
\text { object } \\
\text { research }\end{array}$ & No & $\begin{array}{c}\text { The name of } \\
\text { the subject } \\
\text { as object } \\
\text { research }\end{array}$ & Credit \\
\hline \multirow{11}{*}{$\begin{array}{l}\text { Pedagogical } \\
\text { ability } \\
\text { Prospective } \\
\text { Teacher in } \\
\text { Electrical } \\
\text { Engineering } \\
\text { Education }\end{array}$} & $\begin{array}{l}\text { Educational } \\
\text { Subjects }\end{array}$ & 1 & $\begin{array}{l}\text { Introduction } \\
\text { to education }\end{array}$ & 3 \\
\hline & & 2 & $\begin{array}{l}\text { Learner } \\
\text { development }\end{array}$ & 3 \\
\hline & & 3 & $\begin{array}{l}\text { Vocational } \\
\text { education } \\
\text { curriculum }\end{array}$ & 2 \\
\hline & & 4 & $\begin{array}{l}\text { Learning } \\
\text { and } \\
\text { pedagogy }\end{array}$ & 4 \\
\hline & & 5 & $\begin{array}{l}\text { Learning } \\
\text { resource }\end{array}$ & 2 \\
\hline & & 6 & $\begin{array}{l}\text { Evaluation } \\
\text { of education }\end{array}$ & 2 \\
\hline & & 7 & $\begin{array}{l}\text { Learning } \\
\text { design }\end{array}$ & 3 \\
\hline & & 8 & $\begin{array}{l}\text { Computer- } \\
\text { aided } \\
\text { learning }\end{array}$ & 3 \\
\hline & & 9 & $\begin{array}{l}\text { Micro } \\
\text { Teaching }\end{array}$ & 2 \\
\hline & & 10 & $\begin{array}{l}\text { Vocational } \\
\text { education } \\
\text { management }\end{array}$ & 2 \\
\hline & Total credit & & & 26 \\
\hline
\end{tabular}

The prerequisite test for hypothesis analysis is done before the regression analysis is carried out. The prerequisite test analysis was conducted on the TPACK data as well as the pedagogical abilities of prospective electrical engineering education teachers. From the analysis of the data, the two variables meet the requirements for normality, homogeneity, and linearity. Hypothesis testing is the relationship between TPACK and the pedagogical abilities of vocational teacher candidates for electrical engineering education. This test is done with linear regression which aims to see the relationship between the two variables. Calculation of linear regression analysis using SPSS 17. If $\mathrm{p} \leq 0.05$, then there is a positive and significant relationship between the two variables. However, if $\mathrm{p} \geq 0.05$, there is no positive and significant relationship.

The predictor contribution was used to find out how much TPACK contributed to the pedagogical abilities of vocational teacher candidates for electrical engineering education. Simple regression analytical technique to find the value of $\mathrm{R}$ (Psig < Psig-count) is the relationship between variables. Continued R-square which is a contribution between the TPACK variable on Pedagogical Knowledge of Vocational Teachers in Electrical Engineering Education.

\section{RESULTS AND DISCUSSION}

Grouping data on TPACK variables based on the highest score minus the lowest score, then divided by a scale of four. The results of the study obtained the lowest value of 129 and the highest value of 237 . While the acquisition of the lowest ideal score of 60 and the highest ideal score of 240 , so the interval used in the use of this study is 45 . The distribution of TPACK data can be seen in Table 2. 
Based on these data, it can be seen that the highest number of respondents was 86 respondents with a percentage of $64.7 \%$ located in the interval class 195 to 240 with very high classification. It means that technological pedagogical content knowledge (TPACK) of the undergraduate student with a major in electrical engineering education in Universitas Negeri Malang is very high. The average score of technological pedagogical content knowledge (TPACK) variables obtained by students from the distribution of total scores by the number of students is 200.99 .

Tabel 2. The Distribution of TPACK Data

\begin{tabular}{|c|c|c|c|c|c|}
\hline No & Interval & Classification & Frequency & $\%$ & Average \\
\hline 1 & 195 to 240 & Very High & 86 & 64.70 & \\
\hline 2 & 150 to 194 & High & 48 & 35.56 & \\
\hline 3 & 105 to 149 & Mid & 1 & 0.74 & 200.99 \\
\hline 4 & 50 to 104 & Lower & 0 & 0 & \\
\hline \multicolumn{3}{|c|}{ Total } & 135 & 100.00 & \\
\hline
\end{tabular}

TPACK is known in the world of education is a knowledge framework that shows the relationship between the three knowledge that must be mastered by teachers, namely technological knowledge, pedagogical knowledge, and content knowledge into learning Koehler [12]. This is in line with Hewitt in 2008 which states that TPACK is considered as a potential framework in providing new directions for teachers so that it can solve problems that occur in the classroom by integrating IT into teaching and learning activities in the classroom.

Based on the results of the analysis of indicator data, the highest average score obtained is the pedagogical knowledge indicator $(\mathrm{PK})$ which means students of the electrical engineering education study program in Universitas Negeri Malang have knowledge related to methods, teaching processes, class management, class assessment, and development of learning plans is high, so it is necessary to maintain and also improve it in the future. The lowest average score indicator is an indicator of technological pedagogical content knowledge (TPACK). This implies that every student needs to get used to practicing the three components of knowledge, namely pedagogic knowledge, content knowledge, and technological knowledge in every class learning.

Pedagogical knowledge is the result of data analysis of the total number of educational courses in the electrical engineering education study program in Universitas Negeri Malang batch 2014. The assessment of educational courses is a reference to see the pedagogical abilities of prospective vocational teachers in electrical engineering education. The distribution of data can be seen in Table 3.

Based on the analysis of indicators, the highest average value is obtained in the Micro Teaching Practice course with an average value of 3.69 , while the lowest average value lies in the Vocational Education Management course at 3.10. From the analysis of the indicators, it can be implemented that the Vocational Education Curriculum courses and the Micro Teaching Practice course can improve the pedagogical ability to become teachers of the undergraduate student with a major of Electrical Engineering Education Universitas Negeri Malang batch 2014.

Table 3. Pedagogical Course Value Distribution

\begin{tabular}{|c|c|c|c|c|c|}
\hline No & Interval & Classification & Frequency & $\%$ & Average \\
\hline 1 & 38 to 40 & Very High & 3 & 2.22 & \\
\hline 2 & 34 to 37 & High & 75 & 55.56 & \\
\hline 3 & 31 to 33 & Mid & 52 & 38.52 & 33.45 \\
\hline 4 & 28 to 30 & Lower & 5 & 3.70 & \\
\hline \multicolumn{3}{|c|}{ Total } & 135 & 100 & \\
\hline
\end{tabular}


Table 3 reveals the results of educational learning scores with the highest number of respondents by 75 respondents with a percentage of $55.56 \%$ located in the 34 to 37 interval class with high classification. Based on these data it can be said that the pedagogical abilities of prospective vocational teacher candidates for electrical engineering education are highly classified. The average value is 33.45 .

Table 4. Regression Results

\begin{tabular}{lcc}
\hline Variable Independent & $\begin{array}{c}\text { Regression } \\
\text { coefficient }\end{array}$ & Sig T \\
\hline TPACK (X) & 0.058 & 0.000 \\
\hline Constanta & 14.524 & \\
R & 0.757 & \\
R square $\left(\mathrm{R}^{2}\right)$ & 0.573 & \\
$\mathrm{~F}_{\text {count }}$ & 113.589 & \\
Sig F & 0.000 & \\
\end{tabular}

Based on Table 4, it can be seen that the results of the simple regression analysis test obtained a Fcount value of 113.589 with a Psig value of $0.000<0.05$, so it can be said that there is a positive and significant relationship between TPACK and the pedagogical abilities of vocational teacher candidates for electrical engineering education. $\mathrm{R}^{2}=0.573$ is a determination index value which illustrates that the contribution of TPACK to pedagogical abilities has a value of $57.3 \%$.

The contribution of $57.3 \%$ shows that the pedagogical ability to become a teacher of the undergraduate student of Electrical Engineering Education in Universitas Negeri Malang is strongly influenced by the technological pedagogical content knowledge (TPACK) owned by each student. The higher the technological pedagogical content knowledge (TPACK), the higher the pedagogical ability to become a teacher. With the largest contribution to the pedagogical knowledge (PK) indicator. The results of this study reinforce the statement of Tian, Suryawati, and Arief in 2015 [25] that there is a relationship between technological pedagogical content knowledge (TPCK) on the GPA value of prospective teacher students showing one item that gives a significant influence, namely Technological Knowledge. Research conducted by Ariani in 2015 [26] that technological pedagogical content knowledge has a positive and significant relationship between TPACK and TISE. According to Puspitarini, Wahyu, Sunaryo, and Ermain 2013 [27] that there is a positive and significant influence relationship related to technological pedagogical content knowledge (TPACK), but the contribution that most gave the biggest contribution lies in technical knowledge, which is about the ability of engineering in using technology.

\section{CONCLUSION}

Based on the results of the data analysis and discussion that has been presented, it can be concluded that undergraduate students of Electrical Engineering Education, Faculty of Engineering, Universitas Negeri Malang as prospective vocational teachers of electrical engineering education have high TPACK levels in the category, and have pedagogical abilities in the high category. This study revealed a positive and significant effect between TPACK on the pedagogical abilities of prospective vocational teachers in electrical engineering education. TPACK's contribution to improving the pedagogical abilities of vocational teacher candidates for electrical engineering education is quite significant at $57.3 \%$. It is given that the TPACK contributes to the pedagogical abilities of prospective teachers, 
it is necessary to consider the integration of TPACK in each pedagogical subject in the undergraduate with a major of Electrical Engineering Education, Faculty of Engineering, Universitas Negeri Malang. Not only for the vocational or engineering subject but also pedagogical abilities are needed for the prospective vocational teachers.

\section{REFERENCES}

[1] R. Aji, S. Hartati, and D. Rusmawati, "Hubungan Antara Locus of Control internal dengan Kematangan Karir pada Siswa Kelas XII SMKN 4 Purworejo," J. Ilmu Pendidik., 2012.

[2] J. Wang, E. Lin, E. Spalding, C. L. Klecka, and O. S. J., "Quality Teaching and Teacher Education: A Kaleidoscope of Notions," J. Teach. Educ., vol. 62, no. 4, pp. 331-338, 2011.

[3] D. N. Harris and T. R. Sass, "Teacher Training, Teacher Quality and Student Achievement," 2007.

[4] L. M. Gichuru and P. R. W. Ongus, "Effect of Teacher Quality on Student Performance in Mathematics in Primary 6 National Examination: A Survey of Private Primary Schools in Gasabo District, Kigali City, Rwanda," Int. J. Educ. Res., vol. 4, no. 2, pp. 237-260, 2016.

[5] Ministry of Education and Culture, "Hasil Uji Kompetensi Guru (UKG) Tahun 2015," 2016.

[6] Directorat General of Teachers and Education Personnl, "Hasil Uji Kompetensi Guru 2015," Jakarta, 2015.

[7] G. Kurt, A. Akyel, Z. Kocoglu, and P. Mishra, "TPACK in Practice: A Qualitative Study on Technology Integrated Lesson Planning and Implementation of Turkish Preservice Teachers of English," ELT Res. J., vol. 3, no. 3, pp. 153-166, 2014.
[8] L. L. Taopan, N. A. Drajati, and Sumardi, "TPACK Framework: Challenges and Opportunities in EFL Classrooms," Res. Innov. Lang. Learn., vol. 3, no. 1, pp. 1-22, 2020.

[9] B. Martin, "Successful Implementation of TPACK in Teacher Preparation Programs," Int. J. Integr. Technol. Educ., vol. 4, no. 1, pp. 17-26, 2015.

[10] D. A. Schmidt, E. Baran, A. D. Thompson, P. Mishra, M. J. Koehler, and T. S. Shin, "Technological Pedagogical Content Knowledge (TPACK): The Development and Validation of an Assessment Instrument for Preservice Teachers," J. Res. Technol. Educ., vol. 42, no. 2, pp. 123-149, 2009.

[11] L. Durdu and F. Dag, "Pre-Service Teachers' TPACK Development and Conceptions through a TPACKBased Course," Aust. J. Teach. Educ., vol. 42, no. 11, pp. 150-171, 2017.

[12] N. Alrwaished, A. Alkandari, and F. Alhashem, "Exploring In- and PreService Science and Mathematics Teachers' Technology, Pedagogy, and Content Knowledge (TPACK): What Next?," EURASIA J. Math. Sci. Technol. Educ., vol. 13, no. 9, pp. 6113-6131, 2017.

[13] A. Yani, M. Ruhimat, and A. Mulyadi, "SWOT Analysis of Technological Pedagogical Content Knowledge

(TPACK) Implementation on Geography Learning," IOP Conf. Ser. Earth Environ. Sci., no. 286 012005, 2019.

[14] N. Absari, P. Priyanto, and M. Muslikhin, "The Effectiveness of Technology, Pedagogy and Content Knowledge (TPACK) in Learning," J. Pendidik. Teknol. dan Kejuru., vol. 26, no. 1, 2020.

[15] L. S. Shulman, "Those Who Understand: Knowledge Growth in Teaching," Educ. Res., vol. 15, no. 2, pp. 4-14, 1985. 
[16] Z. Asril, Mikro Teaching. Jakarta: Raja Grafindo, 2010.

[17] S. Sagala, Kemampuan Professional Guru dan Tenaga Kependidikan. Bandung: Alfabeta, 2009.

[18] Trianto, Tinjauan Yuridis Hak serta Kewajiban Pendidik Menurut UU Guru dan Dosen. Jakarta: Prestasi Pustaka, 2006.

[19] W. Rasyidin, Pedagogik Teoretis dan Praktis. Bandung: PT. Remaja Rosdakarya, 2014.

[20] B. Alma, Guru Professional: Menguasai Metode dan Terampil Mengajar. Bandung: Alfabeta, 2012.

[21] E. Mulyasa, Standar Kompetensi dan Sertifikasi Guru. Bandung: Remaja Rosda Karya, 2012.

[22] A. Rosyid, "Technological Pedagogical Content Knowledge: Sebuah Kerangka Pengetahuan Bagi Guru Indonesia di Era MEA,” J. Fak. Ilmu Pendidik. UNS, 2016.

[23] M. . Koehler, P. Mishra, M. Akcaoglu, and J. Rosenberg, The Technological Pedagogical Content Knowledge Framework for Teachers and Teacher Educators. ICT Integrated Teacher Education: A Resource Book. cemca.org, 2013.
[24] Sugiyono, Metode Penelitian Pendidikan: Pendekatan Kuantitatif, Kualitatif, dan R\&D. Bandung: Alfabeta, 2015.

[25] S. . Tian and R. H. Arief, "Profil Technological Pedagogical Content Knowledge (TPCK) Mahasiswa Calon Guru Biologi FKIP Universitas Riau," J. Penelit. Fak. Kegur. dan Ilmu Pendidik. Univ. Riau, 2015.

[26] S. Arikunto, Prosedur Penelitian Suatu Pendekatan Praktik. Jakarta: Rineka Cipta, 2010.

[27] Universitas Negeri Malang, Katalog Fakultas Teknik Jurusan Teknik Elektro Universitas Negeri Malang Kurikulum 2014. Malang: Universitas Negeri Malang, 2014. 